\title{
Aplikasi Pengenalan Pola pada Citra Bola Sebagai Dasar Pengendalian Gerakan Robot
}

\author{
Ratnasari Nur Rohmah \\ Jurusan Teknik Elektro Universitas Muhammadiyah Surakarta (UMS) Surakarta, Indonesia \\ rnr217@ums.ac.id
}

Usman

Jurusan Teknik Elektro Politeknik Negeri Bandung Bandung, Indonesia usmanb@polban.ac.id

\begin{abstract}
Abstraksi- Makalah ini memaparkan aplikasi metode pengenalan pola pada citra bola sebagai dasar pengendalian gerakan robot. Citra bola merupakan data masukan yang diakuisisi dengan kamera pada robot. Data citra pada penelitian ini digunakan untuk: seleksi obyek, jarak obyek ke robot, dan penentu arah gerakan robot. Fitur citra yang digunakan dalam proses pengendalian robot adalah fitur-fitur: warna, bentuk, perubahan ukuran, dan perubahan posisi relatif obyek pada suatu sumbu koordinat. Fitur ciri diperoleh dengan penapisan warna pada runag warna $H S V$, pengenalan bentuk dengan circle Hough transform, perubahan ukuran dengan perbandingan jumlah piksel, dan posisi relatif obyek diperoleh dengan perbandingan jarak horisontal dari titik pusat bola awal ke tepi-tepi bola. Uji coba pada sistem memperlihatkan metode pengenalan pola citra yang diterapkan dapat digunakan sebagai dasar gerakan robot. Hasil uji coba memperlihatkan robot dapat melakukan penjajakan terbaik pada citra dengan resolusi 320x240 piksel, dan memiliki jarak pandang maksimum $113 \mathrm{~cm}$, dan mengenali obyek sampai pada intensitas cahaya minimum 21,1 lux.
\end{abstract}

\section{Katakunci-pengenalan pola; citra; pengendalian}

\section{Pendahuluan (Heading 1)}

Pengenalan pola adalah salah satu penerapan dari pengolahan citra dalam kategori analisis citra. Umumnya tahapan dalam pengenalan pola adalah segmentasi citra atau seleksi obyek, ekstraksi fitur, dan identifikasi. Penelitian menerapkan teknologi penerapan pola untuk menganalisis citra hasil tangkapan kamera suatu robot, dan menggunakannya untuk pengendalian gerakan robot secara real time.

Pemilihan kamera sebagai sensor pada robot adalah untuk menirukan salah satu perilaku manusia dalam menetapkan suatu gerakan. Dengan data yang diperoleh oleh indera mata, seorang manusia bisa mengolah informasi citra yang ditangkap untuk berbagai keputusan dalam melakukan suatu gerakan. Beberapa keputusan gerakan tersebut adalah, obyek mana yang akan diikuti, diikuti atau tidaknya gerakan suatu obyek dan arah gerakan jika keputusannya adalah mengikuti gerakan suatu benda. Keputusan ini bisa ditetapkan bahkan hanya dengan informasi berupa citra yang ditangkap oleh indra mata manusia.

Gerakan yang dirancang untuk dilakukan oleh robot pada penelitian ini adalah gerakan maju-mundur menjauhi atau mendekati suatu obyek tertentu, serta gerakan membelok sesuai arah pergerakan obyek tersebut. Gerakan ini bisa dikendalikan hanya dengan pengenalan citra yang diakuisisi dengan kamera. Penggunaan data citra ini akan meminimalisasi kebutuhan sensor robot dalam melakukan fungsinya.

\section{DASAR TEORI DAN TINJAUAN PUSTAKA}

Beberapa teknik pengolahan citra yang digunakan dalam penelitian ini diantaranya adalah teknik pengubahan ruang warna citra 
dari ruang warna RGB ke dalam ruang warna HSV. Teknik ini digunakan dalam proses segementasi citra untuk seleksi obyek tertentu dalam satu frame citra yang mempunyai beberapa obyek. Segmentasi pada ruang warna ini dipilih karena memberikan identifikasi yang lebih baik terhadap objek dalam sebuah image dibandingkan dengan yang dihasilkan menggunakan ruang warna RGB [1]. Metode ini lebih baik karena metode color filtering RGB untuk segmentasi warna masih belum dapat memahami objek secara akurat disebabkan oleh faktor dari intensitas cahaya yang belum diperhitungkan [2].

Fitur lain yang dikenali pada penelitian ini adalah fitur bentuk obyek. Pada penelitian ini obyek yang akan dikenali oleh robot adalah obyek berbentuk bola. Penelitian ini menggabungkan teknik deteksi tepi dan algoritma hough circles untuk mengenali obyek lingkaran. Algoritma ini merupakan algoritma yang sering digunakan untuk mendeteksi bentuk lingkaran pada sebuah citra dua dimensi [3]. Ukuran suatu obyek citra bisa dilakukan dengan berbagai macam, mulai dari penggunaan rumus geometris, banyaknya piksel, atau pengukuran diagonal obyek. Penelitian ini menggunakan metode sederhana dengan pengukuran diameter lingkaran pada suatu koordinat virtual.

\section{Metode Penelitian}

Pada penelitian ini ciri yang dikenali citra akan digunakan untuk: seleksi obyek, penentuan gerakan maju-mundur, penentuan arah belok robot. Algoritma pengenalan pola dalam penelitian ini adalah sebagai berikut:

i. Penetapan nilai numerik warna citra dalam ruang warna $H S V$ (berdasar eksperimen) yang akan digunakan dalam penapisan warna obyek, penetapan waktu tunda akuisisi citra untuk penetapan gerak.

ii. Akuisisi citra.

iii. Segmentasi citra proses 1: pengubahan ruang-warna citra ke dalam ruang warna HSV, proses penapisan warna, dan penetapan kandidat obyek sesuai hasil proses penapisan warna. iv. Segmentasi citra proses 2: deteksi tepi kandidat obyek dilanjutkan transformasi Hough circle, penetapan obyek.

v. Pengukuran diameter dan posisi citra obyek dalam koordinat virtual, penetapan hasil pengukuran sebagai diameter dan posisi referensi. Gambar 1 berikut memperlihatkan bagaimana posisi obyek ditempatkan dalam koordinat virtual, pengukuran diameter, serta penetapan belok kanan-kiri.

vi. Akuisisi citra obyek setelah waktu tunda.

vii. Pengukuran diameter citra dan perbandingan dengan diameter referensi, penentuan keputusan gerak maju jika diameter lebih besar dari diameter referensi dan sebaliknya.

viii. Pengukuran posisi diameter citra dan perbandingan dengan posisi referensi, penentuan belok kanan jika posisi citra lebih kanan dari referensi dan sebaliknya.

Langkah (vi) sampai langkah (viii) terus dilakukan agar diperoleh pengendalian gerakan robot secara real time, sampai perintah berhenti.

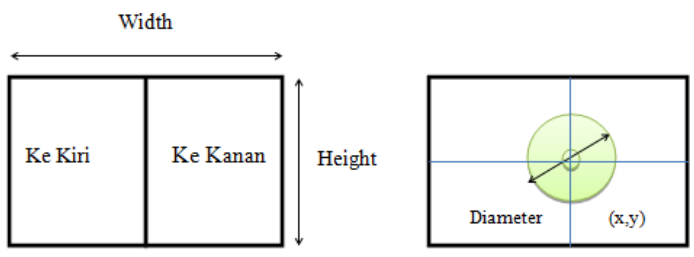

Gambar 1. Koordinat serta diameter gambar bola untuk sistem gerak robot [4].

Pengujian unjuk-kerja sistem yang dibangun pada penelitian ini dilakukan dengan pengujian utama pada ketepatan penentuan obyek oleh robot, ketepatan mengikuti arah gerakan. Selain itu diukur juga unjuk-kerja robot dalam hal kecepatan respon robot atas perubahan gerakan, pengaruh resolusi citra, dan pengaruh pencahayaan saat akuisisi citra.

\section{HASIL DAN PEMBAHASAN}

\section{A. Eksperimen penetapan nilai numerik untuk penapisan warna}

Eksperimen dilakukan dengan menguji coba penetapan beberapa nilai numerik baik 
dalam ruang warna RGB maupun HSV. Hasil eksperimen pada berbagai warna obyek didapatkan nilai numerik untuk kedua ruang warna seperti terlihat pada Tabel 1 dan Tabel 2.

Kedua nilai tersebut kemudian diuji-coba untuk mendapatkan perbandingan penggunaan kedua ruang warna di atas. Uji coba menunjukkan bahwa penggunaan ruang warna HSV menunjukkan jangkauan warna yang lebih akurat dibanding penggunaan ruang warna RGB. Dari uji coba atas citra dengan 8 obyek (Gbr. 2), penapisan warna dalam ruang RGB menghasilkan pengenalan sebagi 10 obyek. Kesepuluh obyek ini adalah warna: merah: 2, hijau: 2, biru: 3; kuning: 3 (Gbr. 3). Sedangkan penapisan dalam ruang warna HSV menghasilkan tepat 8 obyek citra (Gbr. 4).

TABEL I. NILAI NUMERIK OPTIMAL DALAM RUANG WARNA RGB

\begin{tabular}{|l|l|l|l|l|l|l|}
\hline \multirow{2}{*}{$\begin{array}{l}\text { Warn } \\
\text { a }\end{array}$} & \multicolumn{2}{l|l|}{$\begin{array}{l}\text { Nilai } \\
\text { (red) }\end{array}$} & $\begin{array}{l}\text { NilaiG } \\
\text { (green) }\end{array}$ & \multicolumn{2}{l|}{$\begin{array}{l}\text { Nilai } \\
\text { (blue })\end{array}$} \\
\cline { 2 - 7 } & $\begin{array}{l}\text { Mi } \\
\text { n }\end{array}$ & $\begin{array}{l}\text { Ma } \\
\text { x }\end{array}$ & $\begin{array}{l}\text { Mi } \\
\text { n }\end{array}$ & $\begin{array}{l}\text { Ma } \\
\text { x }\end{array}$ & $\begin{array}{l}\text { Mi } \\
\text { n }\end{array}$ & $\begin{array}{l}\text { Ma } \\
\text { x }\end{array}$ \\
\hline Merah & 90 & 255 & 0 & 40 & 20 & 100 \\
\hline Hijau & 10 & 80 & 50 & 150 & 10 & 80 \\
\hline Biru & 0 & 30 & 30 & 170 & 100 & 230 \\
\hline $\begin{array}{l}\text { Kunin } \\
\text { g }\end{array}$ & 170 & 240 & 130 & 220 & 0 & 60 \\
\hline
\end{tabular}

TABEL II. NILAI NUMERIK OPTIMAL DALAM RUANG WARNA HSV

\begin{tabular}{|l|l|l|l|l|l|l|}
\hline \multirow{2}{*}{ Warna } & \multicolumn{2}{|c|}{$\begin{array}{c}\text { Nilai H } \\
\text { (hue) }\end{array}$} & \multicolumn{2}{c|}{$\begin{array}{c}\text { Nilai S } \\
\text { (saturation) }\end{array}$} & \multicolumn{2}{c|}{$\begin{array}{c}\text { Nilai V } \\
\text { (value) }\end{array}$} \\
\cline { 2 - 7 } & Min & Max & Min & Max & Min & Max \\
\hline Merah & 50 & 79 & 50 & 50 & 0 & 55 \\
\hline Hijau & 0 & 100 & 133 & 255 & 30 & 255 \\
\hline Biru & 102 & 139 & 140 & 255 & 30 & 255 \\
\hline Kuning & 0 & 35 & 90 & 255 & 70 & 255 \\
\hline
\end{tabular}

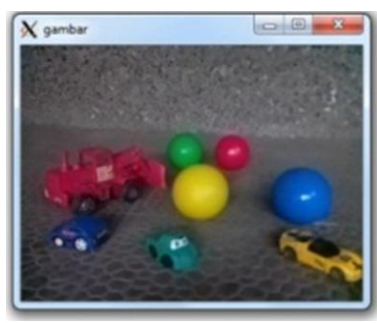

Gambar 2. Satu bingkai citra hasil tangkapan kamera robot

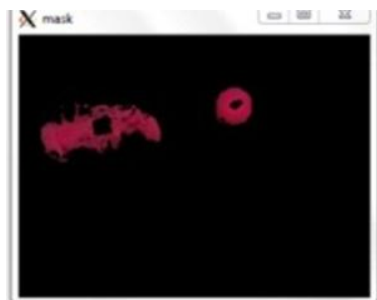

(a)

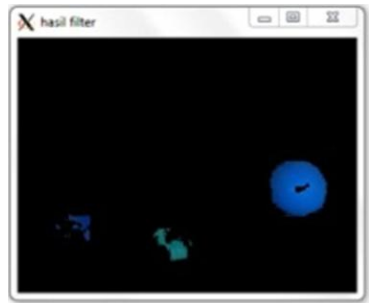

(c)

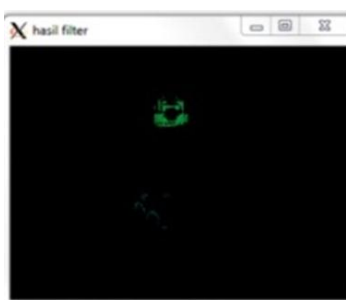

(b)

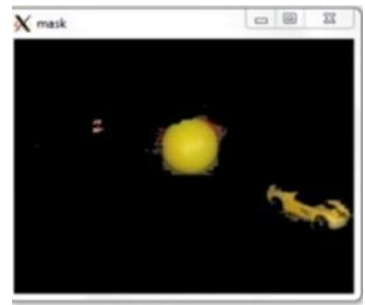

(d)
Gambar 3. Hasil penapisan warna merah (a), hijau (b), biru (c), dan kuning (d) dalam ruang warna RGB

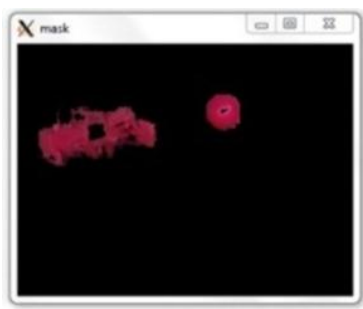

(a)

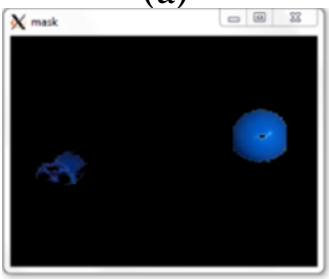

(c)

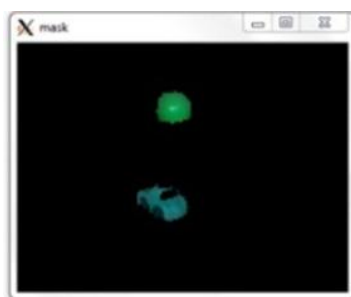

(b)

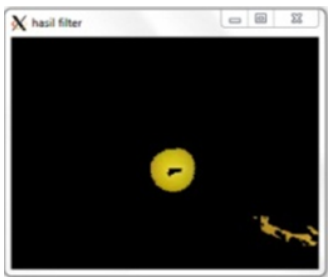

(d)
Gambar 4. Hasil penapisan warna merah (a), hijau (b), biru (c), dan kuning (d), dalam ruang warna HSV

\section{B. Uji-coba kinerja dalam menangkap obyek} bola

Obyek bola yang tertangkap kamera robot dikenali dari bentuk lingkaran pada citra dua dimensi dalam satu bingkai citra. Uji-coba memperlihatkan kombinasi algoritma deteksi tepi dan transformasi Hough circle bisa mendeteksi bentuk ini dari bentuk yang lain. 


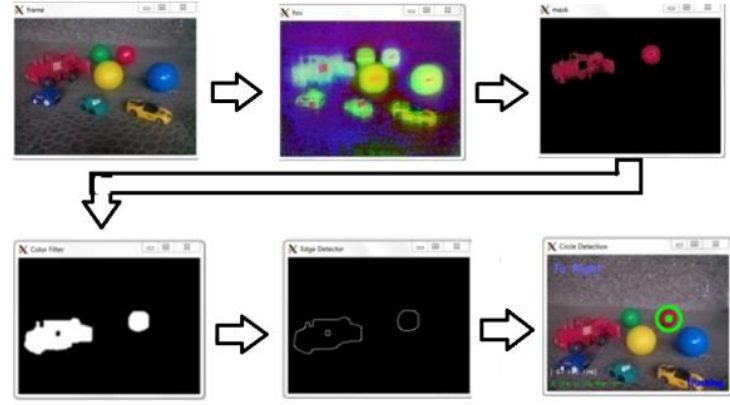

Gambar 5. Proses pengenalan obyek: akuisisi citra, pengubahan ruang warna, penapisan warna, deteksi tepi, dan Hough circle transform

C. Uji-coba Pengaruh Resolusi Citra, Jarak dan Pencahayaan pada Kinerja Sistem.

Uji-coba pengaruh beberapa parameter terhadap unjuk-kerja sistem ini dilakukan dengan menggunakan bola dengan diameter $6.5 \mathrm{~cm}$. Jarak robot dengan objek bola dihitung dari posisi kamera dengan pusat bola, sedangkan waktu tracking objek diambil saat robot bergerak dari posisi awal hingga posisi akhir hingga robot berhenti bergerak karena telah mengenali bola.

Hasil uji-coba menunjukkan resolusi citra berpengaruh baik pada jarak maksimum citra dikenali maupun pada kecepatan identifikasi obyek yang diukur dengan kecepatan respon robot (Tabel 3). Semakin tinggi resolusi citra akan semakin besarnya jarak maksimum bola yang dapat ditangkap citranya. Sebaliknya semakin tinggi resolusi akan semakin memperlambat proses identifikasi obyek. Jarak obyek yang masih bisa ditangkap kamera pada resolusi tertinggi 800x600 piksel adalah $190 \mathrm{~cm}$. Namun demikian pada jarak tersebut data hasil analisis citra tidak bisa digunakan dalam pengendalian robot. Resolusi tertinggi citra dimana hasil analisis data citra dapat digunakan untuk pengendalian robot adalah 480x325 piksel. Citra dengan resolusi lebih tinggi menyebabkan tugas komputasi yang terlalu berat sehingga waktu komputasi yang lama, tidak bisa mengimbagi sinyal umpan balik pada pengendalian gerakan robot.

\section{TABEL III. PENGARUH} RESOLUSI CITRA PADA JARAK
MAKSIMAL DAN WAKTU

PENGENALAN OBYEK

\begin{tabular}{|c|c|c|}
\hline $\begin{array}{c}\text { Resolusi } \\
\text { citra } \\
\text { (piksel) }\end{array}$ & $\begin{array}{c}\text { Jarak } \\
\text { Maksimal }\end{array}$ & $\begin{array}{c}\text { Waktu } \\
\text { Tracking } \\
\text { Objek }\end{array}$ \\
\hline $240 \times 160$ & $102 \mathrm{~cm}$ & 4 detik \\
\hline $320 \times 240$ & $113 \mathrm{~cm}$ & 5 detik \\
\hline $480 \times 320$ & $135 \mathrm{~cm}$ & 6 detik \\
\hline $640 \times 480$ & $172 \mathrm{~cm}$ & error \\
\hline $720 \times 560$ & $180 \mathrm{~cm}$ & error \\
\hline $800 \times 600$ & $190 \mathrm{~cm}$ & error \\
\hline
\end{tabular}

Uji-coba pengaruh pencahayaan terhada kinerja pengenalan obyek diperlihatkan pada Tabel 4 berikut. Pengaruh pencahayaan ini ternyata tidak sama antara keempat warna obyek yang dikenali. Meskipun demikian, dari hasil evaluasi ini robot terlihat cukup peka dalam mengenali obyek pada intensitas cahaya yang cukup kecil (Gbr. 6) dengan intensitas minimum 21,1 lux untuk warna biru.

\section{TABEL IV. PENGARUH INTENSITAS PENCAHAYAAN PADA PENGENALAN OBYEK}

\begin{tabular}{|c|c|}
\hline Warna & $\begin{array}{l}\text { Intensitas Cahaya } \\
\text { Minimum }\end{array}$ \\
\hline Merah & 22.7 lux \\
\hline Hijau & 21.2 lux \\
\hline Biru & 21.1 lux \\
\hline Kuning & 23.6 lux \\
\hline
\end{tabular}
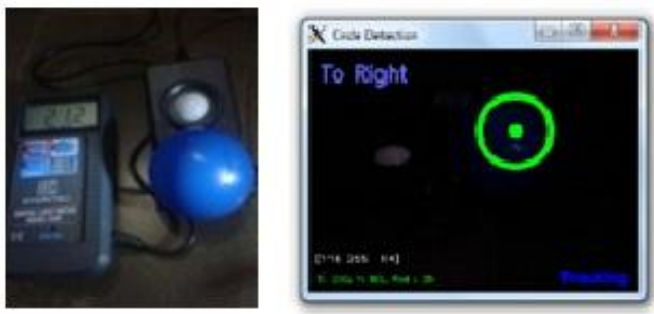

Gambar 6. Pengukuran pencahayaan minimum untuk pengenalan obyek berwarna biru 


\section{KESIMPULAN}

Penelitian ini menunjukkan keberhasilan penggunaan aplikasi pengenalan pola citra sebagai dasar pengendalian gerak robot. Aplikasi ini melibatkan segmentasi citra untuk mengisolasi obyek, penetapan ciri, dan analisis berdasar ciri yang menetapkan gerakan robot. Akurasi pengenalan obyek pada penelitian ini tinggi terbukti dari dikenalinya warna dan bentuk obyek target. Pemilihan penerapan ruang warna HSV dalam hal ini, terbukti meningkatkan akurasi ini.

Seperti pengolahan citra pada umumnya, hasil pengolahan sangat terpengaruh pada kualitas data citranya. Dalam hal resolusi citra, pengaruh resolusi terhadap jarak maksimum dan terhadap kecepatan pengenalan obyek yang nilainya berbanding terbalik. Resolusi citra yang digunakan dalam akuisisi citra oleh karenanya dapat diatur sesuai dengan kemampuan pendeteksian yang diinginkan. Apakah optimum dalam jarak atau sebaliknya optimum pada kecepatan proses pengolahan citra. Kualitas citra juga akan dipengaruhi oleh kualitas pencahayaan saat akuisisi citra. Intensitas terendah bola dapat dikenali dalam penelitian ini tercatat 2,1 lux untuk warna biru.

\section{Daftar Pustaka}

[1] Sural, S., Qian, G., Pramanik, S, "Segmentation and histogram generation using the HSV color space for image retrieval," Proceedings of IEEE International Conference on Image Processing, pp. 589-592, 2002.

[2] Yustinus, P.." "Rancang Bangun Aplikasi Pendeteksi Bentuk Dan Warna Benda Pada Mobile Robot Webcam", Academia, 2012

[3] Ikwuagu, E. "Design Of An Image, Processing Al̈gorithm ForBall Detection", Computing Research Association, 2011. 